\title{
HISTORICAL NARRATIVE AND WISDOM. TOWARDS PREACHING ESTHER "FOR SUCH A TIME AS THIS"1
}

\begin{abstract}
This article considers the problem of preaching OT historical narrative from the point of view of the depiction of God's participation in the drama. It suggests that historical narrative in general depicts a God who reveals himself infrequently, that his presence is normally veiled, and that the reader often has more information about God than the characters in the narrative. The discussion then focuses on Esther where God is resolutely veiled, even from the reader, were it not for the inter-textual references which the competent reader of OT historical narrative will discern. The article suggests that biblical wisdom literature, which discerns God's veiled presence without respect to acts in history, can be employed to profitably preach Esther in a world where God is present, but readers experience him as veiled. The article ends with suggestions for a series of sermons on Esther.
\end{abstract}

Biblical characters have long fascinated Scripture readers: Good deeds received praise and were deemed worthy of imitation; dark deeds were examined for their doctrinal worth. ${ }^{2}$ The four senses of the text - the literal, spiritual, ethical, and eschatological - fostered such readings (Lubac 1998:1-14). Some homileticians and exegetes characterize this approach as "exemplary," that

1 This essay develops a lecture delivered at the Gespreksgroep Bybelwetenskappe at the University of the Free State, Bloemfontein, on May 13, 2009.

2 For classic literature on Bible characters, see Frost 1963; James 1951; Kittel 1968. For an excellent review of the interpretation of difficult texts about characters, going back to the early church, see Thompson 2007.

Dr. Arie C. Leder is Martin J. Wyngaarden Senior Professor of Old Testament Studies at Calvin Theological Seminary, Grand Rapids, Michigan, USA. E-mail: lede@calvinseminary.edu

Acta Theologica

2011 31(2): 135-158

doi: http://dx.doi.org/10.4314/actat.v31i2.7

ISSN 1015-8758

() UVIUFS

<http://www.uovs.ac.za/ActaTheologica> 
is, of reducing the complexities, especially of the historical narratives, to a picture gallery of ethical models. Critics of this position counter that biblical historical narrative is not about models of ethical behavior, but about God's redemptive acts in a history that moves organically to the revelation of Jesus Christ. Biblical historical texts, they argue, should be preached redemptivehistorically, with a clear focus on Christ as the fulfillment. ${ }^{3}$

Although he does not advocate an exemplary approach to biblical historical narrative, Douglas Stuart understands that historical narratives

do not necessarily teach directly, they often illustrate what is taught directly and categorically elsewhere. This represents an implicit kind of teaching, which in cooperation with the explicit teachings of Scripture, is highly effective in generating the sort of learning experience the Holy Spirit can use positively (Fee \& Stuart 1993:82).

Stuart's position suggests that historical texts need something besides themselves to function properly within the Church. It is true, of course, that Christians read the OT in the light of the NT. But, the question of how OT historical narrative was heard before the coming of Christ is not unimportant. Or to question Stuart: May we consider OT historical narrative to be theological literature in its own right? Or is it merely historical? Did this literature teach Israel what to believe or how to behave, or both? Is this literature theological instruction ${ }^{4}$

Redemptive-historical hermeneutics answers this in the affirmative: historical texts, argues Sidney Greidanus, proclaim God's acts in history. Because they have a theocentric, not an anthropocentric, focus these texts are also immediately relevant to the addressees (Greidanus 1970:215; 1988:116121). Using the hermeneutic of redemptive-historical progress OT narrative is then usually read in the light of God's penultimate mighty act in Christ. ${ }^{5}$ Although Stuart argues that historical texts are implicit illustrations of explicit doctrines taught elsewhere, his discussion of the Joseph and Ruth narratives points to the narratives' being explicitly theocentric (Gen. 39:2-5, 21-23; 50:26; Ruth $1: 17 ; 4: 13)$, because neither of the stories are about people.

But are these narratives explicitly theocentric? Are not the Joseph and Ruth stories about people who behave in ways that lead to the well-being of others,

3 The controversy emerged during the 1930s in the Netherlands and had great impact among the Reformed Churches. The controversy and the problem it sought to solve, is examined in detail by Greidanus 1970:22-120.

4 For discussions that argue for a greater importance of the OT vis-à-vis the NT, see Van Ruler 1971; Snyman 2002:126-146; 147-162; Goldingay 2003:23-28.

5 In addition to redemptive-historical progression, Greidanus 1999 develops 6 more ways of preaching the Old Testament theologically with a focus on Christ. 
especially that of God's people? And, does not the so-called Court History of David (2 Sam. 9-20) describe David's personal failures as king, especially against the background of 2 Samuel 8:15? It is true that the narrators and/or characters mention God, and that in this sense the narrative evokes him, but the Joseph and Ruth narratives do not depict God's ways with human beings as do the narratives about Noah, Abraham, Jacob, Samuel, Saul, and even David in 2 Samuel 7. And then there is Esther.

Among difficult preaching texts Esther has pride of place: the narrative depicts no mighty acts of divine grace, blessing or judgment. And, because it does not mention God at all, Esther outperforms even the Ruth, Joseph and David stories, where God appears briefly, if only by narrative comment or by reference in human speech (Ruth 1:6, 20-21; 4:11, 13, 14-15; Gen. 39:2, 5, 9, 21; 50; 43:14; 44:5; 50:19, 24; 2 Sam. 11:27c; 12:1-25; 17:14). Human actors undeniably assume major roles in these narratives. Even more, they initiate the action: Elimelech moves to Moab, Ruth decides to go with Naomi, Boaz speaks to the harvesters in Ruth's favor, Jacob urges Joseph to visit his brothers, and Joseph acts on his own in Potiphar's house and in jail. Only now and then does the narrator inform the reader of God's involvement. In Esther, however, the focus is exclusively on human action. Xerxes, Vashti, Esther, Mordecai and Haman act on their own, without any of the normally expected textual indications of divine involvement or causation.

This essay will examine these and other peculiarities of the Book of Esther with a view to making suggestions for preaching Esther in the Christian Church. Scholarly opinions about its genre and historicity ${ }^{6}$ will only enter the discussion when contributing to the question: What is a good way to approach Esther for preaching? To that end the essay will first examine the nature and readers' expectation of biblical historical narrative. It will then proceed to reflect on how a convergence of narrative and wisdom can provide fertile ground for preaching Esther, especially from the point of view of wisdom.

6 On the relationship of historical criticism and preaching see Bartlett 2008:37-44, in which he spends time on the drawbacks of historical criticism for preaching. $\mathrm{He}$ ends this section thus: "For the Reformers sola scriptura and sola gratia were two ways of saying the same thing. Sola historia was never really an option." Nevertheless, the historical method is useful in checking the sermon in terms of the text's references, providing historical background, keeping preacher in touch with the reality that no one proclaims the Word unfiltered by human scholarship (42-43). For a critique of the usefulness of the historical critical method for the church see Smart 1975. 


\section{EXPECTATIONS OF BIBLICAL HISTORICAL NARRATIVE}

God's textual absence offers an opportunity to reflect on Esther's participation in the biblical depiction of God's way with his people in the world. The crucial questions are: What do readers expect of biblical historical narrative? What does narrative in fact provide? Taking Esther and Genesis 1 as the extremes of a continuum that measures divine and human action in biblical narrative, we note that the latter depicts only divine and the former only human action. In between these texts we encounter narratives closer to Genesis 1, such as the accounts of Abraham and Samuel, and those closer to Esther, such as parts of the Joseph story or the Court History of David in 2 Samuel 9-20. In all these narratives, however, human action is pronounced.

A strong emphasis on human action is to be expected. Biblical characters are not puppets manipulated by a hidden master, but relatively independent actors on a morally ordered stage (Gen. 1:1-2:3) where all creatures, human and otherwise, necessarily respond to that order. Human creatures do so in ways that please God or offend him. Beginning with Genesis 3:1, biblical narrative depicts humanity's pervasively negative response to the moral order, the divine rejoinders of judgment and grace among the nations, and subsequently with Abraham and Sarah and their descendants. God acts and speaks to prevent humanity's escape into autonomy (Gen. 3:23; 11:6), and to redirect it in ways that please him (Gen. 12:1-3), but the biblical characters continue to act within the moral order that obtains from the beginning and which is massively restated in the divine speeches at Sinai, from the Tent of Meeting, and through Moses. It is the burden of biblical historical narrative to depict humanity's response to divine speech, and usually, to depict an explicit divine response or point of view. Because human characters inescapably respond to or are aided by a God who is depicted as involved with humanity, biblical historical narrative is understood to be theocentric. Esther, however, lacks such explicit divine involvement. ${ }^{7}$

Does this mean Esther is not theocentric but resolutely anthropocentric? Commentators avoid that conclusion by arguing that Esther 4:13-14 is a veiled reference to God's participation, because God's absence points to his presence, or they suggest that Esther's many "coincidences" create an umbrella of divine providence within which the characters have their being (Greidanus 1988:116; Van Gemeren 1988:288; Welbedacht 1987: 177; Baldwin 1984:40). They can also indicate a synergism or complementarity of human initiative and divine

7 About Esther Luther said, including 2 Maccabees: "Ich bin dem Buch und Esther so feind, dass ich wollte, sie wären gar nicht vorhanden; den sie judenzen zu sehr und haben viel heidnische Unart." Quoted by Eissfeldt 1964: 693. For discussions on Esther's canonical status, see Bush 1998:39-54; Anderson 1950:32-43. 
actions (Clines 1984:268-271). Such theological readings are congenial to including Esther in the category of biblical historiography, even if dressed up in comic-heroic clothing. ${ }^{8}$ Esther does provide several obvious points of contact with the antecedent biblical narrative, such as Mordecai's (2:5-7) and Haman's family antecedents (3:1), and the date of Passover (3:7). And then there are the more subtle links: Israel's separation from other peoples $(3: 8)$ evokes the separation of the foreign wives in Ezra and, in general, Israel's torah distinctiveness; the decree prepared by Haman (3:13) evokes Pharaoh's attempt to destroy Israel; that "no one could stand against" the Jews because they feared them (9:2) evokes the fear of the Canaanites and God's declaration to Joshua that no one would stand against him (Josh. 1:5; $23: 9 ; 2: 11 ; 5: 1)$; the Jews' relief from their enemies $(9: 16,22, n w h)$ recalls the rest Israel received at the time of Joshua (Josh. 1:15, nwh). ${ }^{9}$

Nevertheless, the considerable differences between Esther and other biblical historical narrative, underscore the difficulty of reading and preaching Esther as biblical historiography, especially as redemptive history. Compared to Genesis-Kings, Chronicles and Ezra-Nehemiah, Esther lacks rehearsals of history (e.g. Neh. 9; 1 Sam. 12; Joshua 24:1-13); God is not an obvious mover of events (2 Chron. 36:22; Ezra 1:1); it does not emphasize torah (Neh. $9-10)$, nor the temple and its ritual. The exile is not a problem as it is in 2 Kings 17:20-23, 23:27 and 24:3, 20 (or Daniel 1); no one pines for Jerusalem; nor do the Jews of Esther identify themselves with the Promised Land. They are comfortable in an exile become Diaspora (Levenson 1997:13-16). Finally, nowhere in Esther are the Jews sanctioned for transgressing torah, typical of the Former Prophets and many parts of the Pentateuch. Even fasting is disconnected from prayer and repentance

The evocation of Israel's ancient enemies and kingship has been sufficient to treat Esther as another, though somewhat alien, among the other histories of God's acts with his people. The more subtle references would support this reading. ${ }^{10}$ But this approach makes more of Esther as "traditional" biblical

8 "The narrator of the Book of Esther recorded historical events but clothed them in a heroic-comic literary framework" (Weiland 2002:151). "The author of Esther is imitating the history writing of the book of Kings not because he wants his story to sound historical, but because he wants it to sound biblical' (Berlin 2001:7).

9 See Leder 2012.

10 This is the solution of the redemptive-historical approach which eschews the common, decontextualized focusing on human characters and action in the historical literature for the illustration of doctrine or Christian virtue or as a way of bridging the historical gap. The controversy arose among the Reformed in the Netherlands in the light of the tradition of using OT narrative as illustrative for doctrine and/or the Christian virtues by way of examining the examples found in the historical literature. Thus Esther is included in the redemptive historical class, 
historical narrative than it is, and fails to take seriously its intentional veiling of the "traditional" depiction of God's acts and Israel's responses. Readers may recognize the narrative intertextuality, but the narrative's characters do not; they are only aware of their Jewishness in an environment bereft of the traditional means for maintaining their identity and shaping their behavior. All told, Esther does not fit the category of "traditional" historical narrative. ${ }^{11}$ It does, however, display similarities to the Joseph story, the so-called Court History of David (2 Samuel 9-20; 1 Kings 1-2), and Ruth, historical narratives in which divine action is minimally represented by narrative commentary or a prophet.

Divine absence in Esther should not, however, be considered a problem, but an opportunity to read a narrative which uniquely reflects the reader's own environment: where God is not obviously active, but still believed to be present with a power to shape human events. Such an environment asks for the resolute practice of wisdom.

\subsection{Historical narrative and wisdom}

Wisdom categories have been employed to understand historical narratives in which God is not overtly active. Thus, God does not reveal himself to Joseph, as he did to the patriarchs, and as he did to Jacob in Egypt (Gen. 46:2-4).12

located between Ezra and Nehemiah. By way of typology, it is argued, Mordecai anticipates Christ (De Graaf 1952:597; Greidanus 1977:22-55; 1988:158-166). For a brief analysis of the problem of preaching historical narrative, see Kromminga 1983:32-46. For a discussion of the historical antecedents of the redemptivehistorical orientation see Becker 2004. His discussion of history suggests that history as a thing itself, and not the text, is the focus of Heilsgeschichte, translated variously as redemptive-historical or salvation-historical.

11 Even as the epistle of James fails to meet the expectation that he teach justification by faith. See, for example, the discussion in Adamson 1976:34-38. Esther and James share challenges to their canonical status because they do not meet the expectations readers of Scripture have developed. They also share similar audiences: the Jewish people of God in the OT, and the Jewish Christians in the NT. Both are scattered among the nations.

12 Gerhard von Rad argues that the Joseph story is a didactic wisdom narrative much like the Court History of David (2 Sam. 9-20; 1 Kings 1-2). He provides convincing examples of parallels to wisdom in the Joseph narrative. In general, he says of this story that "[i]t displays no historico-political interests, nor any cultic, aetiological motive. It is equally devoid of any specifically theological interests in redemptive history" (Von Rad 1966:299). See also Talmon 1963:419-455; Whybray 1968:5695. For a critique of defining Esther as wisdom, see Crenshaw 1969:129-142. We are not arguing that Esther is a wisdom tale, but that studies of Esther as a wisdom tale suggest the usefulness of approaching the synergism (Clines 1984:268-271) 
Unlike Joseph, the reader knows that God blesses Joseph in Potiphar's house (Gen. 39:3, 5), and in prison (Gen. 39:21-23). In each case, Joseph responds to difficult situations without divine instruction. Although Joseph acknowledges God's involvement in his life and in the interpretation of dreams (Gen. 39:9; $40: 8 ; 41: 16$ ), as does Pharaoh (Gen. 41:39), neither is depicted as receiving divine instruction. Rather, Joseph acts wisely. When folly confronts Joseph in the guise of Potiphar's wife, he rejects her, as a wise man would (Gen. 39:710; Prov. 9:13-18; cf. 5:1-6; 7:24-27). God blesses him, but Joseph survives by his wits. Similarly, he interprets the dreams for his fellow inmates and Pharaoh as one gifted to do so, but without divine mediation. Later, the text notes that Joseph has great success in preparing Egypt for the famine, but it does not attribute any of his management skills to God; Joseph is on his own. His world is not closed to divine action, but only the reader knows how and why things happen, thanks to the narrator. From this point of view, Joseph's depicted life in Egypt mirrors the life of $21^{\text {st }}$ century Christian readers who acknowledge and trust in God's power and influence. In difficult situations, any situation, they too must strive for wise decisions on the spot.

The depiction of wise behavior in historical narration also surfaces in the David-Absalom conflict. After Absalom's advisor Ahithophel, recognized for his wisdom (2 Sam. 16:23), counsels Absalom to pursue David and strike him down, Absalom turns to another counselor, Hushai, whose advice is inferior. Absalom takes Hushai's advice because "the Lord had determined to frustrate the good advice of Ahithophel in order to bring disaster on Absalom" (2 Sam. 17:14). The narrator tells the reader of Samuel what the narrative's characters do not know. Absalom decided on a military strategy, but in a world not devoid of God's involvement. Absalom's situation is not unfamiliar to the $21^{\text {st }}$ century Christian reader who also knows that if "man proposes, God disposes" (Prov. 16:9).

Where the Joseph and Absalom narratives include authoritative declarations about God's involvement and management of human affairs, Esther does not. Furthermore, Esther's characters do not acknowledge God after the fact, as do Joseph and Pharaoh. Even more troubling, Esther refuses readers a clear narrative declaration that God himself affected the characters' behavior or eventual outcome. That the characters in the narrative must do without

of Esther from the point of view of wisdom's understanding of the relationship between the deity and humanity. Clines argues (Clines 1984:271) that Loader's positing two levels of meaning, a story of divine acts juxtaposed to one of human action, creates an unnecessary tension between the divine and human elements. However, Loader argues for three levels of meaning, one on the surface and two below. Loader's third level, a story which can "be read as a story of human initiative, action and success (the deliberate veiling of God)," (Loader 1978:421) is the level on which this article focuses. 
God is one thing; readers of the Joseph and Absalom stories are somewhat accustomed to that. Esther confounds readers' traditional expectations of the narrative depiction of divine activity by completely excluding references to God. This uncomfortable gap in the theological landscape is regularly filled by the doctrine of providence, based on Esther 4:14: "if you remain silent at this time, relief and deliverance for the Jews will arise from another place" (Esther $4: 14)$, understanding the phrase "from another place" as confirming that divine providence is firmly in charge.$^{13}$ Esther's refusal to depict God as part of the narrative landscape creates a God-problem for the reader because, in Esther, "God acts under the form of that which is in significant ways opposite to our concepts of God" (Murphy 2002:125).

Positing providence to fill this gap ${ }^{14}$ not only adds to the received text, it also solves a reading problem by resorting to accepted doctrine. Countering this tradition of doctrinal exegesis, Jochen Teuffel argues:

To read Scripture faithfully, it is crucial to abandon the notion of providential cause-effect mechanisms behind the events narrated, because such speculations give rise to pseudo-evangelical 'engineering theology' embracing 'open-view theism' and 'omniscience theism'. ... Occurrences in our 'lived world' are not to be explored in terms of divine causation but they are to be related to God's word (Teuffel 2009:31).

Teuffel's position underscores the question of facing the difficulties of reading Esther as one who needs to discern God's will in everyday life. That providence is a reality is not debatable; reducing it to a mechanism that obviates the difficulties of making wise choices in the face of God's normal veiling, is. That is the issue for readers of Esther.

\subsection{Canonical location: Esther's sapiential neighbor- hood}

The importance of Ruth's canonical placement (Childs 1979:564) ) $^{15}$ is no less true of Esther; its location between Job and the historical books should not be

13 If this was the case, the text should read "the other place," the article specifying the unique place from which such deliverance might arise (Murphy 2002:125).

14 Sternberg's discusses the David and Bathsheba story (1985:186-229) to argue for a sophisticated method of closing gaps which requires careful attention to the text's provisions for such closures. "Illegitimate gap-filling is one launched and sustained by the reader's subjective concerns (or dictated by more general preconceptions) rather than by the text's own norms and directives" (Sternberg 1985:188). For a review and brief evaluation of his position, and a non-biblical intertextual reading of Esther, see Freedman 2005:19-20, 31-32, 105-118.

15 Most recently Seitz 2009:49-76. 
considered a mere accident of history. Reading Esther after Ezra-Nehemiah satisfies the reader because it concludes a relatively chronological ordering of narrative material stretching from the creation and exile from the presence of God to life in the Diaspora. Reading Job after Esther is less satisfactory because it involves a change in genre and unknown historical context. Nevertheless, as with Ruth (Leder 2002:17-22), we offer some avenues for exploring the effects of the juxtaposition of Esther and Job.

Job and Esther have several features in common. Like Esther, Job lacks interest in the land, torah, covenant and cult, and other institutions relevant for exilic and diasporic Jewish identity; Job offers sacrifices, but in this he evokes Noah and Abraham more than post-Sinai temple culture. ${ }^{16}$ Furthermore, only Job's reader knows anything about the connections between the divine world and the protagonist's awful situation on earth. As far as Job is concerned, he's on his own, just like Mordecai and Esther. Only his wits help him against his interlocutors. Without knowing why, Job is forced to account for the disorder in his life and struggle for survival against his friends' misplaced trust in traditional wisdom. As in Esther, Job's concerns are anthropological and practical. The reader who works through the book of Esther and then continues with Job has experienced Esther and Mordecai's behavior under a duress that came upon them for no good reason (Job 1:9; 2:3). Diasporic life under pressure from the ancient enemy, without obvious recourse to God, prepares the reader for Job's devastation by the accuser coupled with God's apparent unconcern. Unlike Mordecai and Esther, however, Job is forced to give an account of his situation by "friends" and, ultimately, by God himself. Both books have "happy" endings, but only of the kind that generally follows on the exercise of wisdom (Prov. 10:6; 11:8). Whatever the historical case for its canonical relocation, reading Job after Esther is hermeneutically more satisfying than doing so after Psalm 150 or Canticles, other canonical locations of Job.

\subsection{God's textual absence: let the reader be wise}

Literature as ancient as Scripture creates numerous problems for any reader. But for readers committed to Scripture as inspired revelation Esther is a special problem precisely because the antecedent historical narrative usually renders explicit in some form God's activities in what readers take to be their everyday world. Even the Joseph and David narratives retain the virtue of sporadic references to God.

Narratives that bristle with divine activity - Abraham's seemingly constant talking with God, or God's intimate attention to Israel in its desert wanderings,

16 In his retelling of Old Testament narrative De Graaf places the Job "narrative" between the narratives about Abraham and Isaac (De Graaf 1952:105-117). 
and even those with less divine activity, such as Ruth - lead Christian believers to accept that as the reality within which they live. Nevertheless, divine selfdisclosures typical of Scripture seldom occur in believers' daily experience, if at all. This difference between the world of Scripture and the contemporary reader does provide an unexpected point of contact, however. The paucity of references to the divine in the Joseph and David narratives, and God's working exclusively behind the scenes, realistically reflects the Christian believer's own experience. Faith understands God's sovereign power and attributes certain events to divine intervention. But that is also a matter of faith and careful discernment, for the Christian Church understands that the last normative divine self-disclosure occurred on the road to Damascus. The next divine revelation, according to the Scriptures, will be the return of Christ and the Last Judgment. In the meantime, only Scripture testifies to God's mighty acts in the past, acts which Christians believe possess a continuing efficacy in the present and provides hope for the future. Christ's death outside Jerusalem will not be repeated; need not be repeated. Unless human experience or history itself become a locus for normative divine revelation, faith focuses not on what God might do in the believer's present, but on what God has done for his people in the past, according to Scripture.

Thus it is that scripturally informed believers accept they are actors on a morally ordered stage (Gen. 1:1-2:3; John 1:1-5), and that there they are called to respond to that order in ways that please God, that do not offend him. Nevertheless, God does not walk with them as he once did with Adam and Eve, Abraham, or the disciples. Believers move and have their being in God's veiled presence; that is the normal post-lapsarian state of affairs. Believers read Scripture to know God's will, and they interpret the events on this world stage in the light of Scripture, for not even believers have special insight into the intricate web of causation which connects the divine to earthly and human reality. Scripture is, so to speak, a portable Sinai: Just as the glory of God descended from Sinai to dwell in Israel's midst, so Christ dwells in the believers' midst by the Holy Spirit, who illuminates our reading and hearing of Scripture. Hence the serious problem of Esther as Scripture: it so resolutely draws the veil that God is practically absent. Thus, Esther is even more difficult to preach than Ruth, for "[f]aith feeds on God's vertical acts on a horizontal plane. But the vertical is no more than suggested [in Esther] and it is immediately horizontalized." 17

If Esther's horizontal plane scandalizes, its depiction of a God veiled from human eyes, even those of the narrator, it is also the key to a more satisfying reading. Erich Zenger, for example, argues that God's veiled presence is

17 Although he does not work with the theme of wisdom, Welbedacht's description of Esther as a diplomat evokes wisdom (Welbedacht 1987:183). 
Esther's theological program: the Jews can be rescued from danger in the world when they "let themselves be led by its historical understanding" (Zenger 1995:209). This historical self-understanding is present in the several obvious and other more subtle evocations of Israel's historical self-understanding and reinforced by the intertextual evocations of the Joseph and Absalom stories. In these narratives the human characters behave according to received historical understanding, one to which Esther makes repeated but only subtle references. Readers familiar with this historical self-understanding cannot miss these references, and will comprehend the narrative web which shapes the characters' behavior. God's frustration of Ahithophel's counsel and his blessing of Joseph with wisdom suggests that the reader supplements the received historical self-understanding with a wisdom that makes its way in a world where God's presence and intervention is normally veiled yet constantly apprehended (Prov. 16:1-9).

Wisdom literature reflects on the same world depicted by biblical historical narrative, one in which God and his creatures are not "totally and irremediably separated. [Qohelet] discerned in creation the veiled presence of God. . . . he was eager to discern God's gift to man in the enjoyment of existence and found a justification for man's devotion in awe before the face of God himself" (Terrien 1978:378). Sapiential reflection on human experience, writes von Rad, "would probably have pointed, not in general terms to the advantages of trusting in God, but to ... the reality and the evidence of the order which controls the whole of life, much as this appeared in the act-consequence relationship." Explicitly linking God to a particular blessing or punishment (Prov. 19:17) only underscores that God is the author of the experienced order and watches over it (Von Rad 1972:191, 129).

Wisdom does not depict a God who behaves as he does in historical narratives - although the tetragrammaton does appear in Job and Proverbs. Esther is similarly bereft of God's obvious historical intervention. Nevertheless, its characters cannot escape the orderliness and act-consequence relationships typical of wisdom, as the abundant irony and peripety of Esther indicates. Esther does not have to be an historicized wisdom tale for wisdom to accompany its nuanced historical self-understanding and so address the problem of God's narrative absence. In this sense a competent reader of Scripture, especially of wisdom, may read the Book of Esther as an answer to the questions: How, when, and with what do God's people respond to deadly persecution? The answer: by your wits, discerning the way of folly and seeking wisdom.

An intimate understanding of the foundational historical narrative (GenesisKings) and wisdom obviates the need to capriciously "fill in the gap," as the Joseph and Absalom stories demonstrate: the wise behavior of God's people ultimately overcomes obstacles; not even the best of human wisdom can 
undermine God's ways, especially those with his people. Similarly Esther. When the ancient enemy threatens the Jews far away from "home," Esther and Mordecai's crafty leadership and wise behavior in dangerous circumstances rescues them. Similarly, Christian readers, as the "twelve tribes scattered among the nations" who will suffer "trials of many kinds" (1:2), are encouraged to survive by the exercise of wisdom (James 1:1, 2, 5; and see 1 Peter 1:1; 4:12-19). ${ }^{18}$ For God's Old and New Testament people in diasporic exile, whose very survival is threatened by the ancient serpent, it is not the time to merely confess God's providence, but to decide what to say or do, how to say or do it, and when to say or do it; ${ }^{19}$ the time to counter folly with wise and crafty action: "Do not answer a fool according to his folly, or you will be like him yourself. Answer a fool according to his folly, or he will be wise in his own eyes" (Prov. 26:4-5).

Who is wise and who is foolish in Esther? Who in Esther answers Lady Wisdom's call (Prov. 1:20-33; 9:1-6)? Who enters the dark doors of Lady Folly (Prov. 9:13-18)? Both Esther and Haman are bound by their historical selfunderstanding. The received biblical tradition adds that successful wisdom is formed and exercised in the fear of the Lord (Prov. 1:7; 9:10), who himself is the author of his people's historical self-understanding. The book of Esther, then, challenges the committed reader to exercise the received historical self-understanding wisely, "for such a time as this" (Esther 4:14). And for everything, there is a time, including war (Eccl. 3:8b). Then, if you perish, you perish (Esther 4:16).

\section{ESTHER: PREACHING FOR SURVIVAL FAR AWAY FROM HOME}

The New Testament, no less than the Old Testament, ends with God's people scattered and persecuted among the nations. Scattered Christians await the New Jerusalem, and an earth in which righteousness dwells; only then will they will be at home. In the meantime, homelessness characterizes the sociohistorical location of God's people, although western Christianity may not even notice this, being too busy enjoying the good life, or building their version of Jerusalem in this corruptible and corrupting world. Elsewhere Christians suffer for the faith: in Darfur, Nepal, Northern Nigeria, and China. Who will

18 It is ironic that both Esther and James have been singled out as not belonging to the canon, because both share the "works" that come from a faithful understanding of being God's people.

19 "The aim of wisdom instruction was, in large measure, the recognition of the right time, the right place, and the right extent of human activity," according to $\mathrm{H}$. $\mathrm{H}$. Schmid, quoted by von Rad 1972:139, n. 3. 
rescue them? God's interest in his people seems unclear from daily events. He seems to be inactive.

And so it was in Babylon. Life was good for Xerxes and his companions. Mordecai was an upstanding citizen sitting at the gate, and Esther just another Jewish girl; but we don't know that until much later, for Jews are not yet important in Xerxes' world. The Jews are enjoying quiet lives in Babylon; they've done no wrong, not in God's eyes, for the narrative records no disapproval of their living in "exile"; nor in the eyes of the Persian emperor. Esther and Mordecai are not treated differently from the many other nationalities in the empire's 127 provinces. It is only when self-respecting Queen Vashti spoils Xerxes' pleasure, that Esther and her cousin are drawn into waters roiled by ancient rip currents. And then, when Mordecai refuses to bend the knee to Haman, all Jews find themselves in mortal peril, for the ancient enemy rears its ugly head, according to the narrative. This time forces Mordecai and Esther to work out their own salvation and that of their people; and that not by faith, but by stealthy works (cf. Phil. 2:12). For such a time as this, prudence alone will overcome the craft of the ancient enemy.

\subsection{The time of the committed reader}

The time of committed readers is shaped by the helter-skelter of local and world events and experiences in a contemporary socio-historical and cultural context shaped by events usually beyond their control. This time has no more resources to accurately detect God's acts and know his purposes in these events than did the people of Noah's days. What is truly knowable about God is suppressed (Rom. 1:18). And if the ancients turned creatures of stone and wood into creators (Rom. 1:22-23), contemporary humanity is no less creative with its own flesh and bone. No one is exempt from such times; all must respond to its exigencies. All are invited to do so wisely; all will be tempted by folly.

Scripture also shapes the time of committed readers. No matter what the socio-historical time of committed readers, Scripture maintains them in the belief that God is truly present in the world, that there is no God like the Father of Jesus Christ, and that he is actively involved in rescuing humanity from its folly. Not merely the product of human religious imagination, this unique resource provides true insight into God's ways with humanity, especially his saving acts which have secured the present and future. Although committed readers have before them inscriptured heavenly wisdom, they are still capable of worldly folly; they are pulled in two directions by these times. Especially in times "such as these," the committed must seek wisdom. 
Like the Jews of Esther, contemporary committed readers may be identified as the dispersed (James 1:1; 1 Peter 1:1) who have no earthly home; their roots are in the desert with the Lord (Leder 2010:291-311). Christian readers live in the dispersion, a time during which the ancient serpent slouches to and fro upon the earth seeking whom he may devour (1 Peter 5:8; Rev. 12:17). The form of this persecution changes from age to age, people to people, and culture to culture. As exiles, committed readers will receive hard or soft invitations to abandon their spiritual identity and so to save their worldly lives.

Although Christian diasporic identity, a homelessness that looks forward to a final divine act, is expressed in a concrete socio-historical situation with its local cultural and sociological challenges, committed readers of Esther familiar with the historical self-understanding formulated by the antecedent historical literature, are urged not to root their identity in any particularity of land or culture (Leder 2010:185-212), but in a faith like that of Abraham (Gen. 15:6; Neh. 9:8, 38; cf. Gal. 3:29). Therefore, the foundational socio-historical context for the committed reader is that of an alien among the nations:

The presence of God is what defines Israel as a people of faith, and the presence of God is thunderously, dangerously mobile. For Ezekiel, 'home' is now hopelessly corrupt; ... old notions of exile will finally be understood to be as meaningless as old notions of home in the presence of God (Sharp 2004:167; and see Scalise 2008:170).

Abandoning old notions of home and identity includes identifying the ancient enemy, the eternal Haman who seeks to wipe out the people of God (Horowitz 2006:81-106; Feldman 2004). Contemporary scholarship discerns this enemy as rooted in particular social experiences: the politically and socially oppressed, the marginalized in terms of gender, status, sexual orientation, and migration. This scholarship encourages those who are abused in some sense by an "other"20 to assume the identity of an exile. While the reality of such marginalization is undeniable, Esther's ancient enemy has no such clear socio-historical location, nor is it defined by cultural or ethnic particularities alone. Rather, Esther's enemy seeks to destroy a peculiar people of faith, not anyone person or group who experiences some kind of marginalization. Who the enemy is at any given time is the almost impossible task of God's people to determine. The list of enemies Jews have identified in their wanderings is long (Horowitz 2006:87-104). Christians have understood the enemy as a historical type who

20 Women (Costas 1988:66-80); African women in particular (Mosala 1992:129-137); emotional exile (Gooder 2002:11-18); and other cultural particularities, including migrants and refugees (Scalise 2008:169-173; Carhuachín 2007:7-19). 
belongs to no one age or nation. He may be a man without power who peddles stories and spreads rumors about the Jews. He may be a man possessing little but a burning hatred of Jewish people, gathering about that fire of enmity those who will persecute and destroy. He may be a man of position who knows what a weapon anti-Semitism is and uses it for his own gain. But whoever he may be, his fate will be the fate of Haman (Lichtenberger 1954:849).

Another aspect of enmity towards the Jews, and Christians, is the constant pressure to adjust the inherited biblical-historical self-understanding to new social and historical situations, to be more tolerant of the "other." This is especially the case since the Enlightenment's feeding suspicion of institutional religion (Barton 1998:121-122), a suspicion which feeds those particularist interpretations of Scripture which argue that the church, and Scripture, has failed to pay attention to women, the oppressed, those of unorthodox sexual orientations, and minorities. In short, the much prized liberal secular pluralism. In his discussion of this phenomenon and Paul's zeal for God, Barton writes that

Paul's overriding concern is to lay down rules and to encourage attitudes and practices which are consistent with the Christian association's primary, theological understanding of itself as "the church of God" and the "body of Christ" in Corinth. Anything which militates in a different direction is outlawed with not the slightest twinge of the liberal pluralist conscience (1998:130).

Barton concludes,

We do not do the cause of a proper tolerance and proper intolerance any favours if we harness Jesus or Paul or early Christianity to the bandwagon of post-Enlightenment secular individualism and pluralism. If we allow that to happen, then we cut off the spiritual, theological and ecclesial roots upon which Christianity's ethic of neighbourly love depends - an ethic itself deeply rooted in the Bible and early Judaism (1998:131).

Christians who have the eyes to see and wisdom to discern, have the burden to respond to "such a time as this" with the awareness of an enemy that seeks to devour God's peculiar people, wherever they gather. The history of exegesis suggests that the enemy takes on peculiar historical and cultural expressions, but the enemy is always one who seeks to swallow God's people, to place obstacles in their journey to the end of the Diaspora. The contemporary preacher must exercise wisdom to discern the enemy and speak to its local, socio-historical, but above all religious, power (Kung 2009). 


\subsection{Texts for this time}

The following expositional suggestions focus on the theme of this essay, using wisdom to preach a series on OT narrative. That is, to combine the evocations of the historical self-understanding Esther provides with wisdom texts to illuminate Esther and Mordecai's action, "for such a time as this." Here and there suggestions about the ancient enemy's modern guise are provided, but we do not go into the socio-historical particulars that face God's people today, for they vary widely, and would require a totally different essay. Links to that discussion have been provided above. The wisdom texts selected are brief, but they are suggestive of the weight of the wisdom tradition, its responsibilities and burdens. Similarly with selections from the NT. Text selection from Esther is guided by the narrative development. Preached as a series they give the audience a taste of the plot and its ironic development in gaining rest from the ancient enemy.

\subsubsection{Advent in Exile (Esther 2:5-9; 3:1-2; James 1:1-4)}

It is crucial to take advantage of the long narrative time taken to get to the fundamental conflict of Esther. Everyone gets along nicely for two chapters, except for Vashti who refuses to be a show piece. Introduced in chapter two, Mordecai creates no fuss when a nice Jewish girl, his cousin, is taken into a Gentile king's harem. The fundamental conflict arises when Mordecai refuses to kneel before Haman. One day all is fine in the kingdom; the next the Jews face annihilation. And for what? One royal descendant fails to pay respect to another royal scion; and it's been centuries since their empires have disappeared. But there is an ancient word about Amalek (Ex. 17:8-16) who are ancestors of Haman; and King Saul (1 Sam. 15:7-11, 17-19), who is a distant ancestor of Mordecai, and who failed to deal with the ancient enemy. Haman's ascendants were renowned for their cruelty (Deut. 25:17-19). Remember, their cruelty, God declares, do not forget my and your enemy (Ex. 17:16). With a few brush strokes the narrator evokes the operative biblicalhistorical self-understanding.

This anchor sermon can move quickly to the solution: Esther and Mordecai's crafty behavior saved the Jews from annihilation. Then it can go on to reflect on the pinch Christians may be experiencing in their culture. Are we willing to think about the ancient serpent seeking whom he may devour? This biblical metaphor itself may be a problem that needs development. For example, is the steady removal of taken for granted public displays indicating the Christian heritage Western churches have long enjoyed, an opportunity to reflect on what Christians could live without; what would they insist on? What 
are the pressures of pluralism and liberal secular notions of tolerance? How does the ancient enemy operate? ${ }^{21}$

James provides a NT connection with suffering in exile and the role of wise behavior as a survival mode. What wisdom, stealth, or craft should Christians practice when the enemy, in whatever historical form he takes, seeks the destruction of God's people? What can the church live without in the public sphere (e.g. Christmas scenes in town squares, prayer in public schools) and what can it not afford to do without (e.g. public worship controlled by its own set of beliefs)? Is now the time for contemporary Christians to suffer? Who and what are we waiting for?

\subsubsection{Timing is Everything (Esther 4:12-5:9a; Eccl. 3:1-8; Prov. 16:15; 25:21-22)}

This sermon sets the challenge for behavior in a time of apparently inevitable doom for God's people. Is this time to speak? Is silence always golden, or sometimes just plain yellow? How does biblical-historical self-understanding inform wise behavior at such a time?

Once the decision is made to act, what is the shape of that behavior? Notice Esther's shrewdness: she uses a banquet - shades of Vashti - to set her plan in motion. She is a greater than Vashti; she makes the king smile (Prov. 16:15). At the same time she asks the Jews to fast, in order to make her feast with the enemy a success! More than that, rather than take the offer of half the kingdom, Esther shrewdly feeds her enemy (Prov. 25:21-22). Haman is completely taken in by Esther. Like a dog returns to its vomit, so a fool to his folly (Prov. 26:11 sets up the next sermon. See Esther 5:9-14).

What threatens Christianity? Who or what is the enemy? Secularity? Islam? Political correctness? Tribalism? Is it a time to embrace or to refrain from embracing? Is this the time of decrease of Christianity in the West and increase in Africa? If so, what does that mean for the survival of the Christian faith elsewhere? Is this the time to embrace suffering as pure joy, as James suggests? And if we perish, is that acceptable? Like the shrewd steward who did what had to be done to please his master (Luke 16:1-9), Esther pleased the king. But not for selfish reasons! Who is our master? Is flattery a proper response to escape persecution?

21 On the ancient enemy's destructive tendency and wiles see C. S. Lewis's The Screwtape Letters (1944). 


\subsubsection{Unstoppable (Esther 5:9-6:14; Mark 4:26-29; Prov. 18:2-3, 7 [Haman], 12 [Mordecai])}

This sermon focuses on the folly of the impossible, like that of stopping a run-away train or avoiding death. Folly makes the fool proud, thus preparing him for his downfall; humility comes before honor. Proverbs 18:12 helps us understand foolish Haman and shrewd Mordecai.

Only one person in the story knows what is impossible: Haman's wife Zeresh (another ironic comment on the role of women in Esther [see 1:18, 20]): since Mordecai is Jewish, you cannot stand against him, you will come to ruin, she tells her husband $(6: 13)$. Haman picked on the wrong people. Sir Folly will have one last meal, at Esther's feet (6:14).

Biblical-historical self-understanding underscores the impossibility of stopping the coming of the kingdom of God. The Canaanites could not stop the Lord's advance under Joshua, not because Joshua was good, or faithful, or smart, but because God was with him (Josh. 1:5). Does Esther act out of this biblical-historical self-understanding? The text does not say. She is shrewd on behalf of her people; a characteristic she shares with Zeresh. This Gentile woman understands Haman's folly.

Why are God's people unstoppable? It has to do with their origins, their identity. Mordecai, with roots in Israel's royalty - a royalty which serves only the Great King - will not bend the knee to anyone on earth. The things humanity deem most important - culture, ethnic origin, sex, "this mortal life" as Luther wrote - come and go, but God's kingdom is forever. It keeps coming all by itself (Mark 4:28). Only a fool gets in the way. The wise, fearing its power, get out of its way, or clamber on board as this train speeds towards God's promised future.

\subsubsection{Doing the king a favor (Esther 7:1-8:2; Prov. 16:12- 16; 29:26; Matt. 10:26-31)}

This sermon focuses on the court of ultimate appeal: the king. Biblicalhistorical self-understanding is rooted in the covenant with God who, as the Great King, is committed to his people by self-maledictory oath (Gen. 15). Wisdom teaches that a good king is like rain on the land, and that only a fool would anger him. The wise seek the king's favor. (Prov. 16:2-5)

Esther has won the king's favor (7:3; and 5:2, 4, 7; 4:8; 2:17), as she had from others $(2: 9,15)$; she exploits it wisely: slavery, she tells the king, would 
have been bearable; but not annihilation. ${ }^{22}$ She pleads for her own life and that of her people (7:3). Although he was the kingdom's second most important official, Haman not only fears for his life - for the king is righteously angry - he adds to his folly by pleading with Esther, on her couch. This scene evokes Joseph who was judged guilty of molesting Potiphar's wife but was innocent. Haman is guilty, if not of molesting the queen, and is hung on the gallows built for Mordecai. Those who dig a pit for others, fall into it themselves (Prov. 16:18); those who do evil to the righteous, only harm themselves (28:10). As do all fools, Haman dug his own grave (Prov. 9:13-18, esp. 18; cf. 1:12).

The kings of the earth cannot exercise the power of the Great King. Fear him, lest he be angry (Ps. 2:12); fear him who has the power over the body and the soul (Matt. 10:28) and requires you to pay to the last penny (Matt. $18: 34 ; 25: 41-46)$. When the ancient serpent threatens, even when believers are hauled before kings and courts, let them seek favor wisely. Above all, let them seek the favor of the Great King, for only he can rescue and keep his people safe from death's destruction. Having the favor of the Great King, we may yet perish in our dealing with an earthly leadership that can help or hinder the faith, but we shall not die. True wisdom is rooted in the fear of the Lord (Prov. 1:9; 9:10); true wisdom gives life (Prov. 3:13-18). And only the Great King can bestow such favor.

And then Mordecai receives Haman's position. Like Joseph he was raised from the pit. Death had its hands around his neck (Jonah 2:5), but was forced to release him (1 Sam. 2:6). With that biblical-historical self-understanding and a behavior rooted in wisdom, and assured of the favor of the king, God's people may assault the ancient enemy with confidence, but not without folly.

\subsubsection{Joy for such a time as this! (Esther 8:3-9:17, 20-22; Proverbs 11:10; Heb. 12:7-11)}

At the end, Esther is about joyous celebration. The day chosen by lot to slaughter the Jews turned into the enemy's defeat because of the persistent shrewdness that managed "this time." The time of suffering is over (Heb. 12:11), for the king has heard Esther's appeal (Prov. 18:17). Now it is a time for joy. A second royal decree gives the Jews the right to defend themselves against the attacks ordered by the first; they may even plunder their attackers (8:11-13).

22 Hiebert (1989:143-157) discusses the missionary implications of the phrase "finding favor." Lichtenberger understands the Christian use of Esther to be one of impartial mission to the nations because the missionary motive among the Jews is lacking (1954:859-863) 
None can stand against the Jews (9:2, cf. Josh. 1:5), but neither is anyone plundered $(9: 10,15)$; for the Jews enjoy relief from the enemy $(9: 16,22$; Josh. $1: 15 ; 21: 44$, the Hebrew word for "relief" is the same). In the great celebration that follows (Prov. 11:10) they also remember the poor (9:22).

How do we remember and celebrate the relief we have received from the great enemy? Can we keep up this joy day after day? Should there be joy at the fall of the enemy? (Herring 1998) The Jews still celebrate Purim once a year. But, after their great joy (Levenson 1997:22), they're back into the daily grind, for the ancient enemy does not take his defeat well. What he began in Eden will continue until the end (1 Peter 5:8; Rev. 12:17). The joy of their relief from the enemy is not endless, but measured, for the end time has not yet arrived. Let every wise generation remember (9:28) the eternal Haman (Horowitz 2006:81-106).

Mordecai, dressed in royal purple, gets the respect and fear a king of the Jews deserves (8:15; 9:3; Prov. 25:6-7); the former persecutors, Gentiles, now fear the Jews, and even join them (8:17). That is the better part of discretion: "Kiss the Son, lest he be angry" (Ps. 2:8). Only fools like Haman fail to perceive the danger $(6: 13)$.

Because the King of the Jews reigns, having dealt the ancient enemy a humiliating defeat (Col. 2:15), there is respite. Christians rejoice in the relief that is theirs through the death and resurrection of Christ, but they will do so wisely, understanding the time in which they live. The time may permit great public joy, or require quiet celebration. Those triumphant in Christ do not gloat when their enemy falls (Prov. 24:17-18), that would be foolish. Nevertheless, those who take refuge in the King of the Jews will always have a reason for joy, no matter the time.

\section{CONCLUDING REMARKS}

Typological and Christological readings of Esther are common. But the NT proffers no antitypes for Esther, as it does for the tabernacle and temple, the sacrifices, the presence of God, and wisdom. Esther is unique among OT historical narratives, as is James among the NT epistles. Both have survived unwise attempts to excise them from Scripture, just like the Jews of Esther's time and beyond have escaped extermination. This is the legacy these books bequeath to the Church composed of Jewish and Gentile believers: always be watchful and wise, especially in those times when the ancient enemy proclaims another decree of destruction. 


\section{BIBLIOGRAPHY}

AdAmson, J.

1976. The Epistle of James. Grand Rapids: Eerdmans.

Anderson, B.W.

1950. The Place of the Book of Esther in the Christian Bible. JR 30.1:32-43.

BALDWIN, J.G.

1984. Esther. An Introduction \& Commentary. Downer's Grove: InterVarsity.

BARTLETT, D.L.

2008. Historical Criticism. The New Interpreter's Handbook of Preaching. Nashville: Abingdon.

BARTON, S.C.

1998. Paul and the Limits of Tolerance. In: G.H. Stanton \& G.G. Stroumsa . Tolerance and Intolerance in Early Judaism and Christianity. (Cambridge: Cambridge University Press), pp. 121-134.

BECKER, M.L.

2004. The Self-Giving God and Salvation History. The Trinitarian Theology of Johannes von Hofmann. New York: T\&T Clark.

BerLin, A.

2001. Esther and Ancient Storytelling. JBL120(1):3-14.

Bush, F.W.

1998. The Book of Esther: opus non gratum in the Christian Canon. BBR 8:39-54.

Carhuachín, C.G.

2007. Hermenéutica desde un contexto de inmigración. CuadTeol 26:7-19.

Carruthers, J.

2008. Esther Through the Centuries. Oxford:Blackwell.

CHILDS B.S.

1979. Introduction to the Old Testament as Scripture. Philadelphia: Fortress.

CLINES D.J.A.

1984. Ezra, Nehemiah, Esther. Grand Rapids: Eerdmans.

Costas, O.E.

1988. The Subversiveness of Faith. Esther as a Paradigm for a Liberating Theology. ER 40:66-80.

Crenshaw, J.L. 1969. Method of Determining Wisdom Influence upon "Historical" Literature. JBL 88(2):129-142.

De GraAF, S.G.

1952. Verbondsgeschiedenis. Schetsen voor de Vertelling van de Bijbelse Geschiedenis, vol. 1. Kampen: Kok. 


\section{EISSFELDT, O.}

1964. Einleitung in das Alte Testament. $3^{\text {rd }}$ ed. Tübingen: J. C. B. Mohr.

FEe, G.D. \& Stuart, D.

1993. How to Read the Bible for All Its Worth. Grand Rapids: Zondervan.

FELDMAN, L.H.

2004. "Remember Amalek!" Vengeance, Zealotry, and Group Destruction in the Bible According to Philo, Pseudo-Philo, and Josephus. Cincinnati:Hebrew Union College Press.

FLeming, J.

1951. Personalities of the Old Testament. New York: Scribner's.

Freedman, A.D.

2005. God as an Absent Character in Biblical Hebrew Narrative. A LiteraryTheoretical Study. New York: Peter Lang.

FROST, S.B.

1951. Patriarchs and Prophets. Montreal: McGill University Press.

Goldingay, J.

2003. Israel's Gospel. Downer's Grove: InterVarsity.

Greidanus, S.

1970. Sola Scriptura. Problems and Principles in Preaching Historical Texts. Toronto: Wedge.

1988. The Modern Preacher and the Ancient Text. Grand Rapids: Eerdmans.

1999. Preaching Christ from the Old Testament. A Contemporary Hermeneutical Method. Grand Rapids: Eerdmans.

HERRING, B.

1998. Should Jews Rejoice When Their Enemy Falls? Tradition 32(2):134-145.

HIEBERT, F.F.

1989. Finding Favor: A Missionary Orientation. Missiology 17(2):143-147.

Horowitz, E.

2006. Reckless Rites. Purim and the Legacy of Jewish Violence. Princeton: Princeton University Press.

KITTEL, R.

1968. Great Men and Movements in Israel. New York: KTAV.

Kromminga, C.G.

1983. Remember Lot's Wife: Preaching Old Testament Narrative Texts. CTJ 18:3246.

KUNG, L.Y.

2009. Love Your Enemies: A Theology for Aliens in Their Native Land: The Chin in Myanmar. Studies in World Christianity 15(1):81-99. 
Leder, A.C.

2002. Reading the Former Prophets by the Rivers of Babylon. CTJ 37:9-27.

2010. Waiting for the Land. The Storyline of the Pentateuch. Philipsburg: Presbyterian \& Reformed.

2010. The Desert Itinerary Notices of Exodus: Their Narrative, Semiotic, and Theological Functions. EstBíb 68(3):291-311.

2012. Hearing Esther after Joshua. Rest in the Exile and the Diaspora. Leuven: Peeters. Forthcoming.

LEWIS, C.S.

1944. The Screwtape Letters. New York: Macmillan.

LEVENSON, J.D.

1997. Esther. Louisville, Ky.: Westminster/John Knox.

LiChtenBerger, A.C.

1954. The Book of Esther. The Interpreter's Bible, vol. 3. New York: Abingdon.

LOADER, J.A.

1978. Esther as a Novel with Different Levels. ZAW 90:417-421.

MURPHY, G.L.

2002. Providence and Passion in Esther. CurTM 29(2):122-127.

SEITZ, C.R.

2009. The Goodly Fellowship of the Prophets. The Achievement of Association in Canon Formation. Grand Rapids: Baker Academic.

SCALISE, P.J.

2008. The End of the Old Testament: Reading Exile in the Hebrew Bible. PRS 35(2):163-178.

SHARP, C.J.

2004. The Trope of "Exile" and the Displacement of Old Testament Theology. PRS 31(2):153-169.

SMART, J.

1975. The Strange Silence of the Bible in the Church. Philadelphia: Westminster

SNYMAN, S.D.

2002. Die Verstaan en Funksie van die Ou Testament in die Kerk (of: Kan die Kerk Klaarkom sonder die Ou Testament? AcT 22:126-146.

Sternberg, M.

1985. The Poetics of Biblical Narrative: Ideological Literature and the Drama of Reading. Bloomington, Ind.: Indiana University Press.

TALMON, S.

1963. "Wisdom" in the Book of Esther. VT 13(4):419-455. 
TERRIEN, S.

1978. The Elusive Presence. The Heart of Biblical Theology. San Francisco: Harper \& Row.

TEUfFEL, J.

2009. The Book of Esther as Guidance to a Canonical Reading of Scripture. CurTM 36(1):122-127.

THOMPSON, J.L.

2007. Reading the Bible with the Dead. What You Can Learn from the History of Exegesis That You Can't Learn from Exegesis Alone. Grand Rapids: Eerdmans.

VANGemeren, W.

1988. The Progress of Redemption. The Story of Salvation from Creation to the New Jerusalem. Grand Rapids: Zondervan.

Van Ruler, A.A.

1971. The Christian Church and the Old Testament. Grand Rapids: Eerdmans.

Von RaD, G.

1966. The Joseph Narrative. The Problem of the Hexateuch and other essays. London: SCM.

1972. Wisdom in Israel. Nashville: Abingdon.

Welbedacht, K.

1987. Ester. Diplomate en Advokaat van het Volk van God. Kampen: Kok.

WEILAND, F.S.

2002. Historicity, Genre, and Narrative Design in the Book of Esther. BSac 159:151165.

WhyBRAY, R.N.

1968. The Succession Narrative. A Study of II Sam. 9-20 and I Kings 1 and 2. Naperville, III.: Alec R. Allenson.

ZENGER, E.

1995. Einleitung in das Alte Testament. Stuttgart: Kohlhammer.

Keywords

Esther

Preaching

Historical narrative

Wisdom

\section{Trefwoorde}

Ester

Prediking

Historiese narratief

Wysheid 